УДК 378.147:004: [373.3.011.3-051:811.111]

Гаврілова Людмила Гаврилівна

доктор педагогічних наук, доцент, завідувач кафедри теорії і практики початкової освіти ДВНЗ «Донбаський державний педагогічний університет», Слов'янськ, Україна ORCID ID 0000-0003-1814-5323

lusjamuz64@gmail.com

Ябурова Олена Володимирівна

кандидат педагогічних наук, доцент кафедри теорії і практики початкової освіти ДВНЗ «Донбаський державний педагогічний університет», Слов’янськ, Україна ORCID ID 0000-0003-4633-2900

primetime3311@gmail.com

Ішутіна Олена Свгенівна

кандидат педагогічних наук, асистент кафедри теорії і практики початкової освіти ДВНЗ «Донбаський державний педагогічний університет», Слов’янськ, Україна

ORCID ID 0000-0002-7801-4205

olenaishutina@gmail.com

\title{
ФОРМУВАННЯ ПРОФЕСІЙНОЇ КОМПЕТЕНТНОСТІ МАЙБУТНІХ УЧИТЕЛІВ АНГЛІЙСЬКОЇ МОВИ ПОЧАТКОВОЇ ШКОЛИ ЗАСОБАМИ ІКТ
}

\begin{abstract}
Анотація. У статті висвітлено результати експериментального впровадження засобів ІКТ у формування професійної компетентності майбутніх учителів англійської мови початкової школи. Серед напрямів використання електронних навчальних засобів, запропонованих авторами: розроблення і застосування тренажеру «Introduction to Interactive Communication» як локального електронного ресурсу з англійської мови; упровадження дистанційних курсів «Практична граматика англійської мови», «Лінгвокраїнознавство»; робота в електронних сервісах, опанування програм інфографіки під час вивчення навчальної дисципліни «Методика навчання англійської мови». Аналіз результатів дослідження засвідчив підвищення мотивації до навчання, зокрема до застосування засобів IКТ на уроках англійської мови, й довів ефективність обраних напрямів формування професійної компетентності майбутніх учителів англійської мови початкової школи.
\end{abstract}

Ключові слова: професійна компетентність; майбутні вчителі англійської мови; електронний тренажер; електронні навчальні сервіси.

\section{1. ВСТУП}

Постановка проблеми. Переформатування шкільної освіти, що наразі відбувається в Україні, активне обговорення проекту «Нової української школи», оприлюдненого Міністерством освіти і науки України у 2016 році [1], засвідчують актуальність проблеми формування професійної компетентності майбутніх учителів англійської мови початкової школи, оскільки вивчення іноземної (англійської) мови за новим Державним стандартом початкової освіти починається з першого класу. Увага до професійної підготовки вчителів англійської мови в початковій школі вимагає наукового осмислення iї специфіки, урахування вікових особливостей молодших школярів, оновлення підручників, розроблення нових навчальних засобів, залучення інноваційних технологій і методик.

Формула нової української школи передбачає також створення сучасного інформаційно-освітнього середовища, яке повинно забезпечити необхідні умови, засоби і технології для навчання учнів, освітян, роботи з батьками. Мається на увазі інтенсифікація процесу інформатизації навчальних закладів, системне використання IКТ в освіті: «наскрізне застосування інформаційно-комунікаційних технологій в 
освітньому процесі й управлінні закладами освіти і системою освіти має стати інструментом забезпечення успіху нової української школи» [1, с. 7].

Аналіз останніх досліджень і публікацій. Проблема формування професійної компетентності майбутніх учителів англійської мови у вітчизняній науковопедагогічній літературі висвітлена достатньо широко (О. Бігич, Н. Гальскова, Н. Гез, Ю. Гудима, Н. Слухіна, Н. Жеренко, В. Златніков, С. Захарова, Л. Куліш, Н. Москальова, С. Ніколаєва та ін.), різні аспекти вивчення англійської мови проаналізовано в численних зарубіжних дослідженнях (А. Абрамс (A. Abrams), Л. Бахман (L. Bachman), М. Гоцкетт (M. Hockett), С. Дукер (S. Duker), А. Палмер (A. Palmer), Ш. Ріксон (Sh. Rixon) та ін.). Проте, наукове осмислення професійної підготовки учителів іноземних мов, зокрема англійської, у початковій школі зустрічається лише в окремих наукових розвідках. Назвемо, передусім праці О. Бігич, яка запропонувала власну концепцію методичної освіти майбутніх учителів іноземних мов початкової школи [2].

Іншомовну методичну компетенцію як один із ключових компонентів структури професійної компетентності майбутнього вчителя початкової школи вивчають О. Котенко та Ю. Руднік [3], які вказують на актуальність формування професійнометодичних умінь учителя використовувати сучасні технології, методи та прийоми в навчанні іноземної мови з урахуванням індивідуально-психологічних особливостей учнів. Як сукупність ключових, базових та спеціальних компетенцій розглядає професійну компетентність вчителя англійської мови початкової школи О. Кміть. Попри це, авторка надає наукове осмислення інформаційної компетентності як необхідного компонента професійної підготовки педагога [4], [5].

Підготовка майбутнього вчителя іноземної мови засобами інформаційнокомунікаційних технологій найгрунтовніше проаналізована у дослідженні I. Костікової [6], яка довела, що цей процес доцільно здійснювати в умовах інформаційнонавчального середовища на основі взаємодії «студент - комп’ютер - викладач».

Мета статті полягає у висвітленні результатів експериментального впровадження засобів ІКТ у формування професійної компетентності майбутніх учителів англійської мови початкової школи.

У дослідженні представлено деякі аспекти роботи викладачів кафедри теорії i практики початкової освіти Державного вищого навчального закладу «Донбаський державний педагогічний університет» 3 розроблення і використання в освітньому процесі комп'ютерних засобів навчання для забезпечення якісного процесу фахової підготовки студентів спеціальності 013 - Початкова освіта (спеціалізація «Англійська мова»).

\section{2. ТЕОРЕТИЧНІ ОСНОВИ ДОСЛІДЖЕННЯ}

Науково-теоретичне підгрунтя дослідження становлять базові категорії компетентнісного підходу: «компетентність» разом із вітчизняними науковцями Т. Байбарою, Н. Бібік, О. Локшиною, О. Овчарук, О. Пометун, О. Савченко та ін. ми тлумачимо як результативно-діяльнісну характеристику освіти, як рівень діяльності, необхідний i достатній для досягнення спрогнозованого результату [7, с. 51]; «компетенцію» розглядаємо як заздалегідь задану соціальну вимогу (норму) до освітньої підготовки учня, що необхідна для його продуктивної діяльності в певній cфepi.

Актуальними $є$ положення сучасної теорії і практики інформатизації освіти, висвітлені в роботах вітчизняних (В. Биков, М. Жалдак, М. Лещенко, Ю. Машбиць, 
Д. Прокудін, І. Роберт, О. Спірін, М. Шишкіна, А. Яцишин та ін.) і зарубіжних учених (Д. Белшоу (D. Belshaw), П. Гілстер (P. Gilster), Г. Дженкінс (H. Jenkins), Дж. Стоммел (J. Stommel), A. Феррарі (A. Ferrari) та ін.). Вважаємо, що сучасна професійна підготовка майбутніх учителів має відбуватися в умовах електронного (віртуального, хмарного) освітнього середовища. У тлумаченні поняття «навчальне середовище» ми спираємось на визначення В. Бикова та В. Кременя: це штучно і цілеспрямовано побудований у навчальному закладі суттєвий оточуючий учня простір (що не включає самого учня), у якому здійснюється навчально-виховний процес і створені необхідні й достатні для його учасників умови щодо ефективного і безпечного досягнення цілей навчання і виховання [8, с. 7].

Застосовуючи електронні засоби навчання під час експериментального пошуку ефективних форм i методів формування професійної компетентності майбутніх учителів англійської мови початкової школи, ми виходимо з розуміння електронного навчального видання як програмного засобу навчального призначення для використання в навчально-виховному процесі (В. Биков, К. Бугайчук, В. Волинський, О. Красовський, В. Лапінський, 3. Савченко, М. Шишкіна, О. Чорноус, Т. Якушина та ін.). Зокрема, електронний навчальний посібник ми визначаємо як навчальне електронне видання, що доповнює або частково (повністю) замінює підручник, у якому рівнозначно і взаємопов'язано за допомогою відповідних програмних засобів існує текстова, звукова, графічна та інша інформація, що забезпечує безперервність і повноту дидактичного циклу процесу навчання, служить для групового, індивідуального або індивідуалізованого навчання, відповідає навчальній програмі й призначене для використання у навчальному процесі (К. Бугайчук [9]).

\section{3. МЕТОДИКА ДОСЛІДЖЕННЯ}

Експериментальне дослідження проводилося на базі факультету початкової, технологічної та професійної освіти Державного вищого навчального закладу «Донбаський державний педагогічний університет» упродовж 2015-2017 років. Об'єкт дослідження - процес професійної підготовки майбутнього вчителя англійської мови початкової школи. Учасники експерименту - студенти освітньо-кваліфікаційного рівня «Бакалавр» спеціальності 013 - Початкова освіта (спеціалізація «Англійська мова»). Для вирішення завдань дослідження було використано комплекс методів: теоретичних (аналіз наукових і науково-методичних джерел з проблем використання IКТ у фаховій підготовці майбутніх учителів іноземної мови, систематизація та узагальнення зібраної інформації) й емпіричних (бесіди, анкетування, педагогічний експеримент).

Дослідження виконане в межах комплексної наукової теми «Професіоналізм педагога: теоретичні й методичні аспекти» (державний реєстраційний номер 0115U003313) кафедри теорії і практики початкової освіти ДВНЗ «Донбаський державний педагогічний університет».

\section{4. РЕЗУЛЬТАТИ ДОСЛІДЖЕННЯ}

Експериментальний пошук сучасних форм і методів професійної підготовки майбутніх учителів англійської мови початкової школи вимагає уточнення понятійного апарату. Аналіз науково-теоретичних джерел, систематизація та узагальнення наявного практичного досвіду професійного розвитку майбутніх філологів різних освітніх ланок дозволяє структурувати категорію професійної компетентності майбутніх учителів англійської мови початкової школи у три компоненти: методичний, інформаційно- 
комунікаційний i комунікативний. Вважаємо, що занурення майбутніх педагогів до електронного навчального середовища, розроблення й використання онлайн та оффлайн електронних освітніх ресурсів, дистанційних курсів, опанування низки програмних засобів (LearningApps, Hot Potatoes, Test X, Kahoot), інфографіки як засобів навчання дозволяють впливати на формування професійної компетентності майбутніх фахівців.

Експериментальному впровадженню електронних засобів навчання передувало діагностичне вимірювання вихідного рівня сформованості професійної компетентності майбутніх учителів на основі інтерактивних технологій (методична розробка О. Ішутіної [10]).

Розглянемо основні напрями використання електронних навчальних засобів у професійній підготовці майбутніх учителів англійської мови початкової школи.

\section{1. Розроблення i застосування навчально-методичного тренажеру як локального електронного ресурсу з англійської мови}

Для забезпечення розвитку в майбутніх учителів навичок аудіювання, говоріння, зокрема діалогічного спілкування, засвоєння лексичного матеріалу відповідно до вимог їхньої професійної підготовки було розроблено електронний навчально-методичний тренажер «Introduction to Interactive Communication» - навчальний електронний посібник, що супроводжує викладання таких професійно зорієнтованих курсів, як «Практика усного і писемного мовлення» i «Основи інтерактивної комунікації». Тренажер пропонується для використання під час групового й індивідуального навчання, містить текстову, аудіо, графічну та іншу інформацію, що забезпечує безперервність і повноту дидактичного циклу процесу навчання.

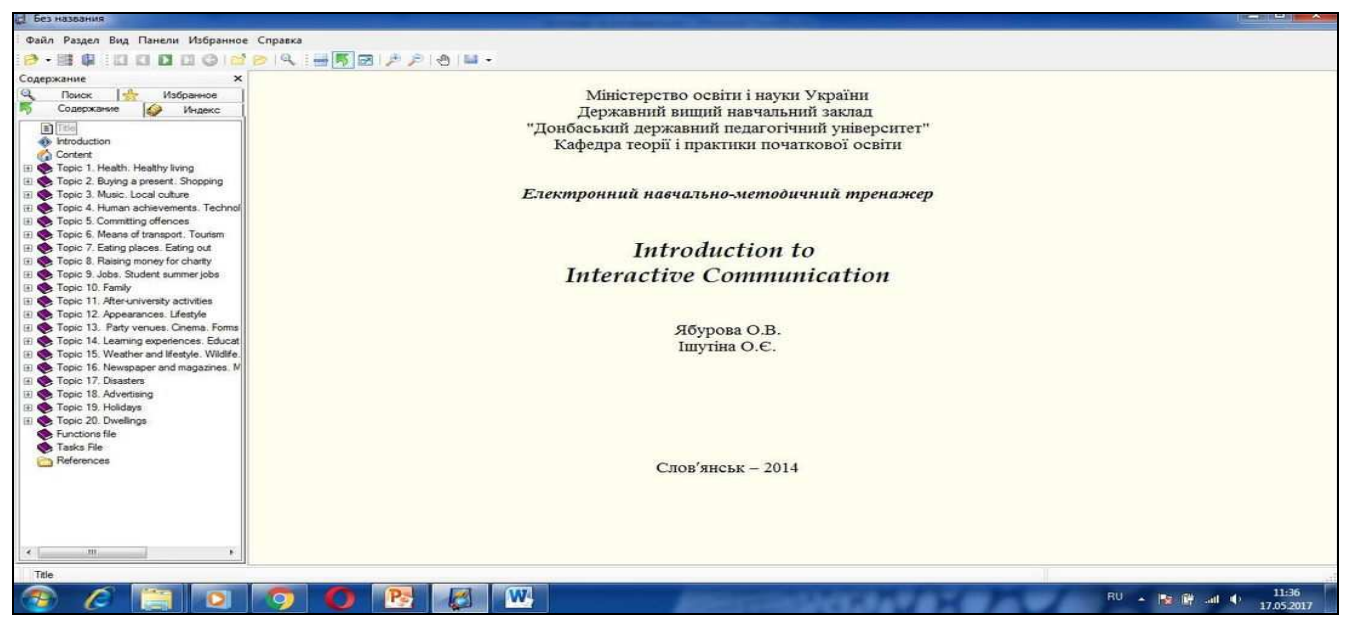

Рис. 1. Титульний екран електронного навчально-методичного тренажера

Відзначимо, що електронний навчально-методичний тренажер «Introduction to Interactive Communication» повною мірою реалізує положення Загальноєвропейських Рекомендацій з мовної освіти [11]. Його створення зумовлене необхідністю пошуку нових інтенсивних шляхів і засобів мовної освіти, що переходить на новий зміст, а це, безумовно, потребує застосування нової сучасної методики. Відтак навчальнометодичний тренажер репрезентує новостворюване покоління електронних видань для вищої освіти.

Тренажер «Introduction to Interactive Communication» створений у програмі SunRav BookOffice $з$ дотриманням таких принципів: 
1. Принцип урахування загальнодидактичних вимог, що втілюється шляхом поєднання освітньої мети і розроблення змістового наповнення на основі поєднання дидактичних підходів: компетентнісного, системного, проблемного, програмованого, проектного, евристичного та ін.

2. Принцип модульності, який передбачає розподіл матеріалу на тематичні блоки ситуативно-мовленнєвого спрямування (модулі), кожен 3 яких має уніфіковану структуру і $є$ логічно завершеним.

3. Принцип наочності. Кожен модуль електронного тренажера містить текстову інформацію, що супроводжується різними видами наочності, серед яких: ілюстрації для полегшення розуміння усного i писемного мовлення, для легшого створення комунікативних ситуацій; умовно-графічна наочність (таблиці і схеми), які сприяють узагальненню і систематизації матеріалу модулів; аудіонаочність - зразки автентичного усного мовлення на запропоновану тему.

4. Принцип розгалуження, що передбачає систему гіперпосилань, що пов'язує модулі між собою для зручного і вільного користування електронним тренажером. Опрацювання тем за вибором студента може бути послідовним чи довільним, що забезпечується гіперпосиланнями всередині тренажера.

5. Принцип самостійності, який забезпечується можливістю кожного студента вільно обирати той чи інший вид роботи, тему, час і тривалість занять. Використання тренажера не потребує специфічних вимог до апаратного забезпечення: не потрібно встановлювати додаткові програми, він працює з операційною системою Windows (7, Vista, 8, 10), немає обмежень щодо оперативної пам'яті тощо.

Структура електронного тренажера чітка: визначено зміст і обсяг обов'язкового для засвоєння лексичного матеріалу, окреслено логіку й послідовність засвоєння тем майбутніми вчителями початкової школи відповідно до вимог навчальної програми. Належний науковий рівень викладу теоретичного матеріалу вдало поєднується 3 його доступністю.

Розроблення тренажера як електронного навчального засобу базується на найновіших здобутках мовознавчої, педагогічної, методичної та психологічної наук, забезпечує додержання принципів особистісно зорієнтованого навчання, комунікативно-діяльнісного підходу, а також наступності й перспективності 3 урахуванням вікових та індивідуальних особливостей студентів.
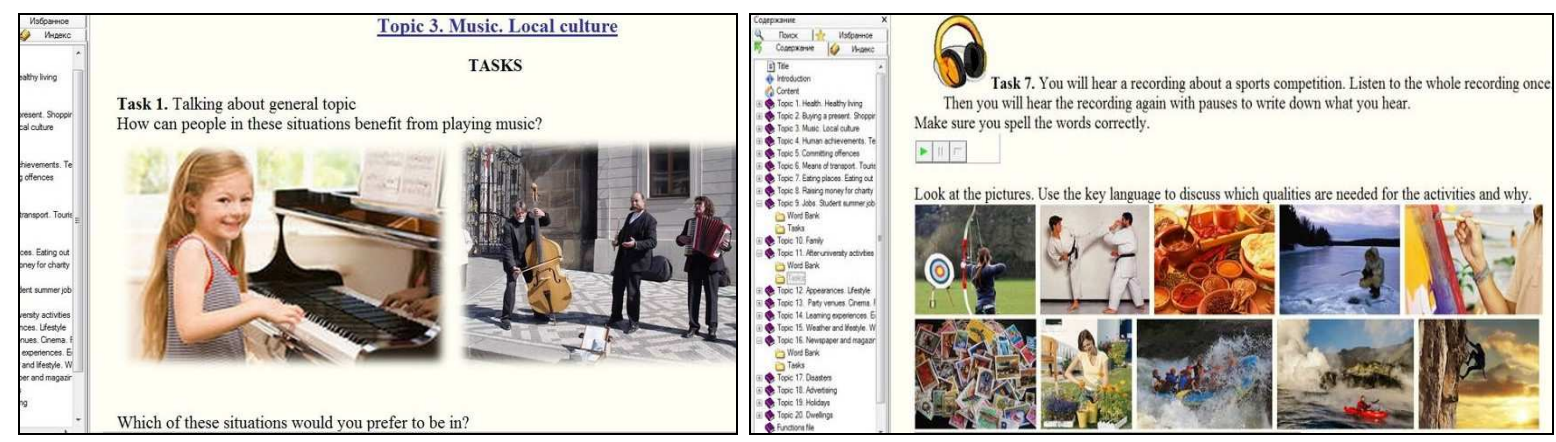

Рис. 2. Приклади завдань в електронному тренажері «Introduction to Interactive Communication»

Навчання говоріння в тренажері ставить за мету розвиток умінь спонтанного непідготовленого спілкування, а не відтворення завчених текстів. Автори пропонують систему мовленнєвих вправ проблемного характеру, які пов'язані з необхідністю опису, порівняння, протиставлення, аналізу, оцінювання та формулювання висновків, аргументування тощо. 
Безперечним позитивом електронного тренажера $\epsilon$ значна увага авторів до розвитку умінь і навичок аудіювання: розроблено систему завдань на основі аудіотексту, виконання яких сприятиме формуванню вміння сприймати на слух i розуміти не лише фактичний зміст прослуханого, а й головну думку аудіотексту, причинно-наслідкові зв'язки між висвітленими в ньому фактами та явищами.

Особливий інтерес становить подана в тренажері система ситуативних вправ для розвитку умінь і навичок усного діалогічного спілкування, що є важливою умовою повноцінного опанування іноземної мови.

Отже, застосування електронного навчально-методичного тренажера «Introduction to Interactive Communication» під час іншомовної підготовки майбутніх учителів початкової школи сприятиме грунтовному опануванню ними іноземної мови, розвитку інформаційно-комунікаційного та комунікативного компонентів професійної компетентності студентів.

\section{2. Використання дистанційних курсів у практиці професійної підготовки майбутніх учителів англійської мови початкової школи}

Одним з ефективних напрямів формування професійної компетентності майбутніх учителів англійської мови початкової школи $\epsilon$ впровадження технології едистанційного навчання: наразі для студентів освітньо-кваліфікаційного рівня «Бакалавр» спеціальності 013 - Початкова освіта (спеціалізація «Англійська мова») успішно організовано роботу в дистанційних курсах 3 дисциплін «Практична граматика англійської мови», «Лінгвокраїнознавство» та ін. Розробляючи дистанційні курси як основну форму реалізації дистанційного навчання, ми розглядаємо їх як спроектовану викладачем навчальну діяльність для засвоєння структурованої інформації, як відтворення традиційного навчального процесу засобами IКТ (спілкування, співробітництво, співтворчість, самостійна робота тощо) (В. Кухаренко [12, с. 53].

Фактично включення до навчального процесу професійного розвитку майбутніх учителів англійської мови початкової школи дистанційних курсів демонструє реалізацію принципів змішаного навчання, яке, за влучним висловом В. Кухаренка, дозволяє скористатися гнучкістю і зручністю дистанційного курсу та перевагами традиційного класу [12]. Ознайомлення з теоретичним матеріалом, виконання завдань самостійної роботи, спілкування 3 викладачем на відстані органічно поєднується 3 традиційними формами навчальної діяльності в аудиторії.

Дистанційні курси «Практична граматика англійської мови» i «Лінгвокраїнознавство» спроектовані за відомою моделлю розробки педагогічного сценарію навчального курсу для електронного середовища навчання ADDIE, яка складається 3 п'яти етапів: аналіз (змісту, навчального середовища, визначення предмету, можливостей програмного забезпечення та апаратних засобів); власне проектування (визначення очікуваних результатів навчання, методів навчання та способу оцінювання, деталізація змісту з точки зору тем); розроблення (підготовка всіх навчальних матеріалів, вправ, завдань, тем проектів та ін., планування організації курсу та його завантаження в систему управління навчанням); упровадження (проведення навчання, організація взаємодії зі студентами); оцінювання (визначення, чи досягнуті навчальні цілі, чи потрібно коригування змісту й методів навчання) [13].

Відзначимо інтенсивне залучення засобів мультимедіа до всіх видів навчальної діяльності в дистанційних курсах, що зумовлене необхідністю комплексного формування всіх видів мовленнєвих умінь, а також лінгвометодичного та інформаційно-комунікаційного складників професійної компетентності майбутніх учителів англійської мови початкової школи. Саме під час опанування іноземної мови 
доцільно синтезувати аудіо-, відео-,та графічну інформацію, що забезпечує оптимізацію якості навчання, а також сприяє підвищенню мотивації навчальної діяльності студентів.

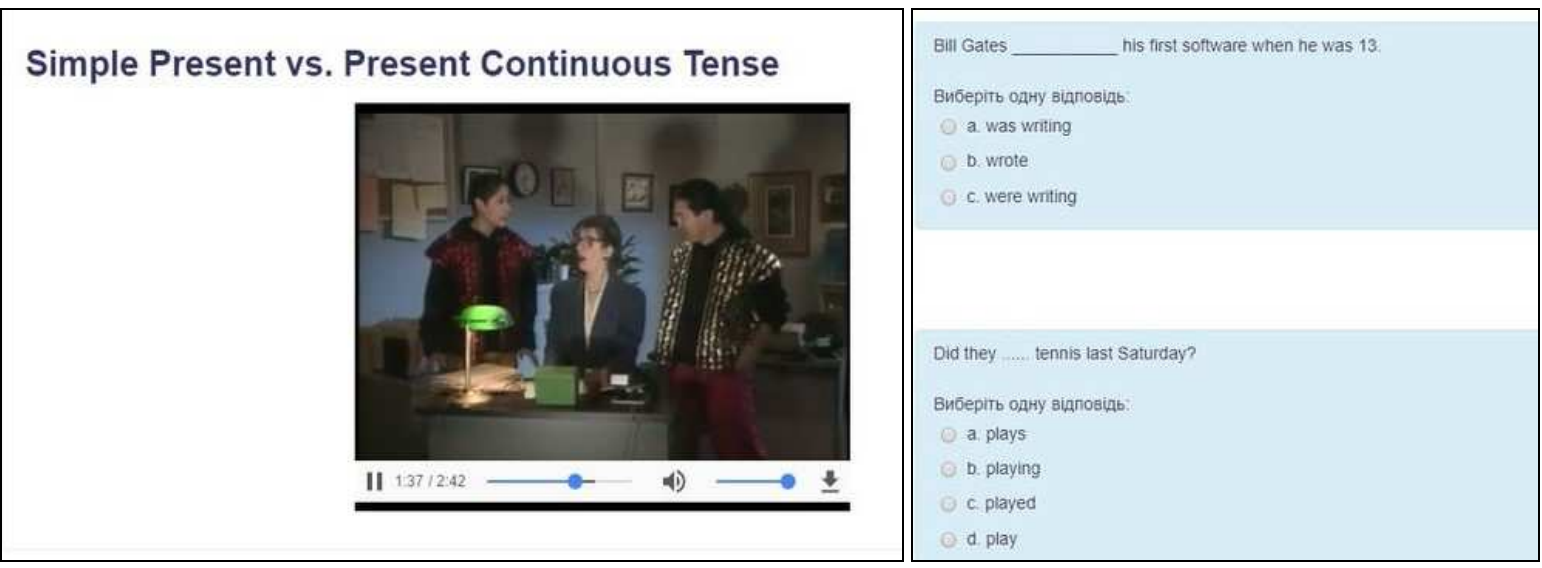

Рис. 3. Приклади навчального відео і тестових завдань в дистанщійному курсі «Практична граматика англійської мови»

Систематична робота 3 автентичним мовленням, представленим у навчальних аудіо- та відеозаписах, що супроводжують лекції і практичні завдання, позитивно впливає передусім на формування комунікативного компоненту професійної компетентності майбутніх педагогів, зокрема навичок мовленнєвої діяльності.

Упровадження дистанційних курсів у професійну підготовку майбутніх учителів англійської мови початкової школи дозволяє зробити навчальний процес більш гнучким, ураховувати індивідуальні освітні потреби студентів, індивідуальний темп освоєння ними навчального матеріалу тощо.

\section{3. Робота майбутніх педагогів у навчальних електронних сервісах}

Ефективний напрям формування професійної компетентності майбутніх учителів англійської мови початкової школи складає використання інтернет-сервісу LearningApps як конструктора для розробки різноманітних завдань з мультимедійним контентом, програм Hot Potatoes, Test X, Kahoot як універсальних оболонок для створення інтерактивних тестових завдань з використанням текстової, графічної, аудіота відеоінформації. Опанування названих електронних сервісів відбувається під час вивчення навчальної дисципліни «Методика навчання англійської мови», яка $\epsilon$ центральною і системоутворювальною в професійній підготовці майбутніх учителів англійської мови початкової школи. У змісті курсу - вивчення модуля «Використання ІКТ під час навчання молодших школярів іноземної мови», засвоюючи який, студенти навчаються створювати електронну продукцію навчально-мовного призначення, а також застосовувати іiі на уроках англійської мови в початковій школі. Спочатку майбутні фахівці набувають досвіду роботи з комп'ютерними засобами навчального призначення як користувачі, а потім випробовують свої сили в розробленні методично обгрунтованих і призначених саме для учнів молодшого шкільного віку інтерактивних завдань, використовуючи LearningApps, Hot Potatoes, Test X, Kahoot, розробляючи мультимедійні тестові завдання, інтерактивні кросворди та ін.

Корисним $є$ також опанування студентами програм інфографіки, які дозволяють власноруч створювати інтелектуальні мапи, інтерактивні плакати: Cacoo, Piktochart, 
Stat Planet, easel.ly тощо, соціальної мережі Glogster, програми для розроблення презентацій Prezi як альтернативи традиційній PowerPoint.

Практична реалізація вказаного напряму формування професійної компетентності майбутніх учителів англійської мови початкової школи здійснювалася не лише в межах вивчення «Методики навчання англійської мови», а й під час практичної підготовки студентів, яка проходила в Лінгвістичному центрі Prime Time (м. Слов'янськ), а також в ході проведення професійно зорієнтованих навчально-виховних заходів: Фестивалю англійської мови «Learn and Play», Регіональної олімпіади з англійської мови для учнів початкових класів тощо.
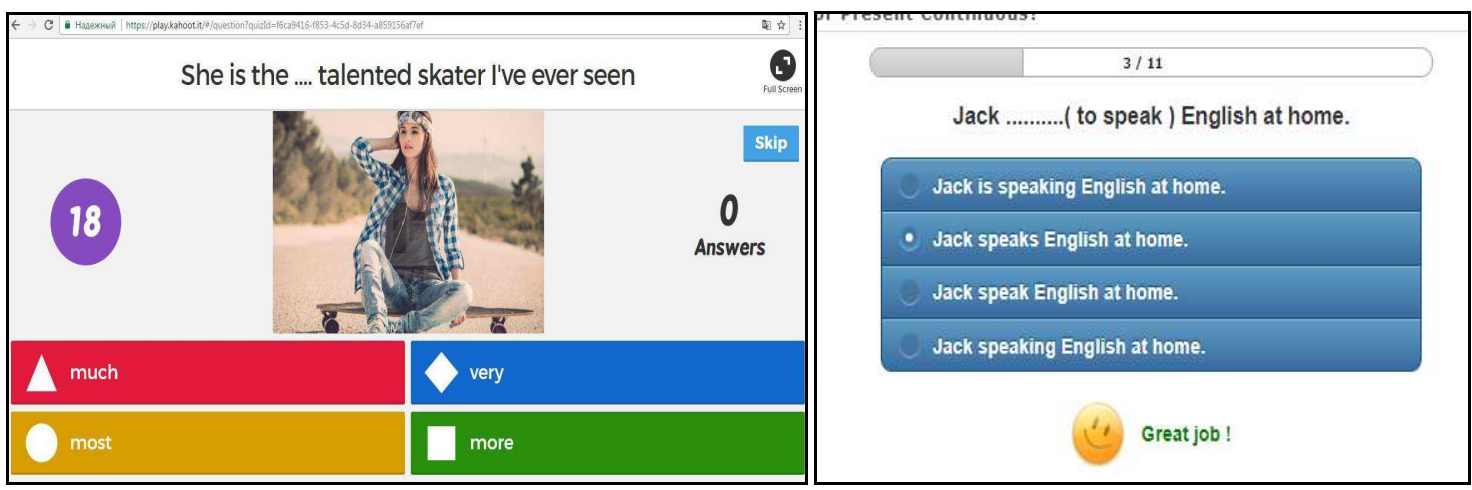

Рис. 4. Приклади тестових завдань, створених студентами в інтернет-сервісах Kahoot i LearningApps

Процес формування професійної компетентності майбутніх учителів англійської мови початкової школи засобами електронних навчальних сервісів було розподілено на три етапи:

- діагностико-коригувальний (для корекції змістового наповнення модуля «Використання ІКТ під час навчання молодших школярів іноземної мови» курсу «Методика навчання англійської мови» й забезпечення оптимального рівня засвоєння інформації студентами на основі врахування їхнього рівня тестологічних знань, умінь та навичок);

- навчально-регулятивний (як цілеспрямовану діяльність викладача 3 формування в студентів готовності до застосування комп'ютерних технологій і засобів у навчанні молодших школярів англійської мови, зокрема формування мотивації до використання IКТ у майбутній професійній діяльності, інформаційної грамотності у галузі лінгводидактики, розвитку технологічних навичок і креативності у розробленні та користуванні електронними навчальними засобами тощо);

- аналітико-результативний, на якому відбувалося визначення рівня ефективності запропонованих форм і методів використання електронних навчальних сервісів, окреслення перспектив подальшого експериментального пошуку.

\section{5. ВИСНОВКИ ТА ПЕРСПЕКТИВИ ПОДАЛЬШИХ ДОСЛІДЖЕНЬ}

Для узагальнення результатів експериментального впровадження засобів ІКТ у формування професійної компетентності майбутніх учителів англійської мови початкової школи та для підбиття проміжних підсумків експериментального навчання було проведено бесіди й електронне анкетування студентів за допомогою Google Forms. Майбутнім учителям було запропоновано оцінити зручність користування електронним тренажером «Introduction to Interactive Communication», вказати на 
переваги його застосування в навчальному процесі, зазначити, з яким саме інтернетсервісом було працювати найцікавіше, який із видів інфографіки виявився найкориснішим у практичній діяльності з молодшими школярами тощо. Відповіді майбутніх учителів англійської мови початкової школи щодо зручності роботи 3 етренажером розподілились так, як подано на рис. 5:

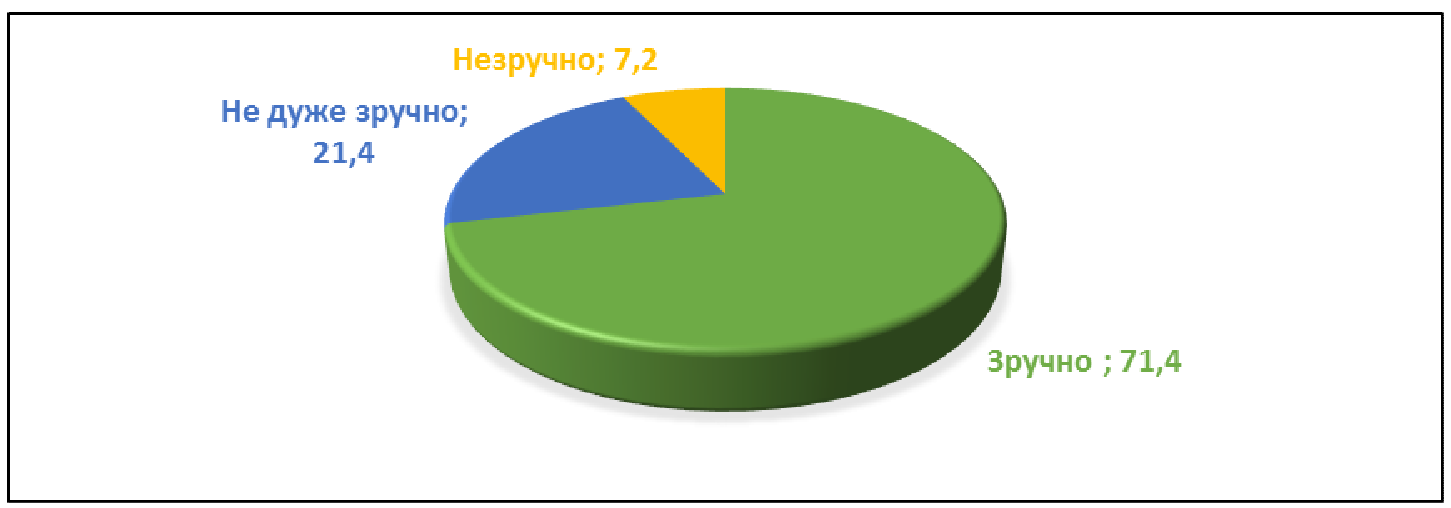

Рис. 5. Оиінка студентами зручності користування електронним тренажером

До переваг використання тренажера майбутні вчителі англійської мови початкової школи зарахували його мультимедійність $(64,3 \%)$, простий і зрозумілий інтерфейс (78,6\%), наявність автентичних аудіоматеріалів (42,9\%) тощо. Запитання анкети «Які корисні знання, уміння і навички ви отримали під час вивчення змістового модуля «ІКТ у навчанні англійської мови в початковій школі» курсу МНАМ?» було одним з найбільш інформативних: усі без виключення студенти вказали Kahoot як найулюбленіший сервіс для роботи, також захоплення майбутніх педагогів викликали LearningApps (64,3\%), сервіси Google (35,7\%), створення інтерактивних плакатів $(21,4 \%)$.

Про вмотивованість до активної професійної діяльності свідчить готовність кожного 3 респондентів до використання набутих умінь у роботі з молодшими школярами. Підвищення мотивації до навчання, зокрема застосування засобів IКТ на уроках англійської мови у початковій школі, доводить позитивна динаміка відвідування студентами лекційних і практичних занять. Збільшення якісного рівня професійної підготовки фахівців засвідчують дані порівняльного аналізу підсумкового контролю (екзамен) у 2015-2016 та 2016-2017 навчальних роках: зростання якості й абсолютної успішності навчання майбутніх учителів англійської мови початкової школи становить відповідно 8,2\% та 5\%.

Отже, процес формування професійної компетентності майбутніх учителів англійської мови початкової школи засобами інформаційно-комунікаційних технологій (електронний навчально-методичний тренажер «Introduction to Interactive Communication», дистанційні курси з професійно зорієнтованих дисциплін, навчальні інтернет-сервіси, програми інфографіки) виявився ефективним, зросла мотивація студентів до навчання, розвинулись акмеологічні лінгвометодичні прагнення майбутніх учителів англійської мови початкової школи.

У перспективі подальшого наукового пошуку - створення локальних засобів електронної лінгвометодики для ВНЗ з усіх дисциплін лінгводидактичного циклу, формування лінгвометодичної хмари, розроблення дистанційних курсів 3 інших навчальних дисциплін освітньо-професійної програми підготовки майбутніх учителів англійської мови початкової школи. 


\section{СПИСОК ВИКОРИСТАНИХ ДЖЕРЕЛ}

[1] Нова українська школа: концептуальні засади реформування загальної школи [Електронний pecypc].

Доступно: http://mon.gov.ua/\%D0\%9D\%D0\%BE\%D0\%B2\%D0\%B8\%D0\%BD\%D0\%B8\%202016/08/17/mon.pdf. Дата звернення: Липень 12, 2017.

[2] О. Бігич, Теорія i практика формування методичної компетенцї вчителя іноземної мови початкової школи. Київ, Україна: Ленвіт, 2006.

[3] О. Котенко, Ю. Руднік, “Моделювання процесу підготовки вчителів початкової школи до застосування інноваційних технологій навчання іноземних мов”, Імідж сучасного педагога, № 10 (169), c. 34-39, 2016.

[4] О. Кміть, Структура і зміст професійної компетентності вчителя англійської мови початкової школи, [Електронний ресурс]. Доступно: http://bo0k.net/index.php?p=achapter\&bid=14834\&chapter=1. Дата звернення: Липень 10, 2017.

[5] О. Кміть, “Зміст інформаційної компетентності вчителя англійської мови початкової школи”, Вісник Чернігівського національного педагогічного університету ім. Т. Г. Шевченка, № 110, с. 222$224,2013$.

[6] І. Костікова, Підготовка майбутнього вчителя іноземної мови засобами інформаційнокомунікаційних технологій. Харків, Україна: Колегіум, 2008.

[7] О. Пометун, “Теорія та практика послідовної реалізації компетентнісного підходу в досвіді зарубіжних країн”, Компетентісний підхід у сучасній освіті : світовий досвід та украӥнські перспективи : бібліотека з освітньої політики. Ред О. В. Овчарук. Київ: К.І.С., 2004, с. 16-25.

[8] В. Биков, В. Кремень, "Категорії простір і середовище: особливості модельного подання та освітнього застосування", Теорія і практика управління соиіальними системами / [Електронний pecypc]. // 2013. №2. С. 3-16. - Режим доступу: http://lib.iitta.gov.ua/id/eprint/1188. Дата звернення: Липень 9, 2017.

[9] К. Бугайчук, “Електронний підручник: поняття, структура, вимоги”, Інформаційні технологї $i$ засоби навчання, № 2(22), 2011. [Електронний ресурс]. Доступно: http://www.journal.iitta.gov.ua. Дата звернення: Липень 9, 2017.

[10] О. Ішутіна, “Використання інтерактивних технологій у моніторингу професійної лінгвометодичної компетентності студентів-філологів”, Професіоналізм педагога: теоретичні й методичні аспекти, № 2, 2015 . $155-163$, [Електронний ресурс]. Доступно: http://pptma.dn.ua/files/2015/2/19.ishutina.155-163.pdf Дата звернення: Липень 10, 2017.

[11] Загальноєвропейські Рекомендації з мовної освіти: вивчення, викладання, оцінювання. Ред. С. Ю. Ніколаєва. Київ: Ленвіт, 2003.

[12] В. М. Кухаренко, “Системний підхід до змішаного навчання”, Інформаційні технологї̈ в освіті, № 24, c. 53-67, 2015. DOI:10.14308/ite000568.

[13] M. Simonson, S. Smaldino, M. Albright \& S. Zvacek, Teaching and learning at a distance: foundations of distance education, 5th Edition. University of Kansas, US, 2012.

Матеріал надійшов до редакичї 17.07.2017p.

\section{ФОРМИРОВАНИЕ ПРОФЕССИОНАЛЬНОЙ КОМПЕТЕНТНОСТИ БУДУЩИХ УЧИТЕЛЕЙ АНГЛИЙСКОГО ЯЗЫКА НАЧАЛЬНОЙ ШКОЛЫ СРЕДСТВАМИ ИКТ}

\section{Гаврилова Людмила Гавриловна}

доктор педагогических наук, доцент, заведующий кафедрой теории и практики начального образования ГВУЗ «Донбасский государственный педагогический университет», Славянск, Украина ORCID ID 0000-0003-1814-5323

lusjamuz64@gmail.com

\section{Ябурова Елена Владимировна}

кандидат педагогических наук, доцент кафедры теории и практики начального образования ГВУЗ «Донбасский государственный педагогический университет», Славянск, Украина ORCID ID 0000-0003-4633-2900 primetime3311@gmail.com 


\title{
Ишутина Елена Евгеньевна
}

кандидат педагогических наук, ассистент кафедры теории и практики начального образования ГВУЗ «Донбасский государственный педагогический университет», Славянск, Украина

ORCID ID 0000-0002-7801-4205

olenaishutina@gmail.com

\begin{abstract}
Аннотация. В статье представлены результаты экспериментального внедрения средств ИКТ в формирование профессиональной компетентности будущих учителей английского языка начальной школы. Среди направлений использования электронных учебных средств, предложенных авторами: разработка и применение учебно-методического тренажера «Introduction to Interactive Communication» как локального электронного ресурса по английскому языку; внедрение дистанционных курсов «Практическая грамматика английского языка», «Лингвострановедение»; работа в электронных сервисах, овладение программами инфографики во время изучения дисциплины «Методика обучения английскому языку». Анализ результатов исследования показал развитие акмеологических лингвометодических стремлений студентов, повышение мотивации к обучению, в частности к применению средств ИКТ на уроках английского языка, и доказал эффективность выбранных направлений формирования профессиональной компетентности будущих учителей английского языка начальной школы.
\end{abstract}

Ключевые слова: профессиональная компетентность; будущие учителя английского языка; электронный тренажер; электронные обучающие сервисы.

\section{FORMING THE PROFESSIONAL COMPETENCE OF THE FUTURE ENGLISH LANGUAGE TEACHERS OF PRIMARY SCHOOL USING ICT}

\author{
Liudmyla H. Havrilova \\ Doctor of Pedagogical Sciences, Associate Professor, Head of Primary Education Theory and Practice \\ Department \\ SHEE «Donbas State Pedagogical University», Sloviansk, Ukraine \\ ORCID ID 0000-0003-1814-5323 \\ lusjamuz64@gmail.com \\ Olena V. Yaburova \\ $\mathrm{PhD}$ (Pedagogical Sciences), Associate Professor of Primary Education Theory and Practice Department \\ SHEE «Donbas State Pedagogical University», Sloviansk, Ukraine \\ ORCID ID 0000-0003-4633-2900 \\ primetime3311@gmail.com \\ Olena Ye. Ishutina \\ PhD (Pedagogical Sciences), Assistant of Primary Education Theory and Practice Department \\ SHEE «Donbas State Pedagogical University», Sloviansk, Ukraine \\ ORCID ID 0000-0002-7801-4205 \\ olenaishutina@gmail.com
}

\begin{abstract}
The paper is devoted to the results of experimental implementing ICT into forming the professional competence of future English teachers of primary school. Among the ways of using the electronic educational means offered by the authors there are: developing and using the educational and methodological simulator «Introduction to Interactive Communication» as a local electronic resource on English; implementing the distance learning courses «Practical English Grammar», «Linguistic Country Study» in future specialists' professional training; work in the electronic services, mastering the programs of infographics during studying the discipline «Methodology of Teaching English». The analysis of the study results showed developing of students' acmeological linguomethodological aspirations, increasing the motivation for learning, in particular the use of ICT tools in English classes, and proved the effectiveness of the chosen ways of forming the professional competence of future English teachers of primary school.
\end{abstract}

Keywords: professional competence; future English language teachers; electronic simulator; elearning services. 


\section{REFERENCES (TRANSLATED AND TRANSLITERATED)}

[1] New Ukrainian school: Conceptual basis of reforming comprehensive school [Online]. Available: http://mon.gov.ua/\%D0\%9D\%D0\%BE\%D0\%B2\%D0\%B8\%D0\%BD\%D0\%B8\%202016/08/17/mon.pdf. Accessed on: July 12, 2017. (in Ukrainian).

[2] O. Bihych, Theory and Practice of Forming Methodological Competence of Foreign Language Teacher of Primary School. Kyiv, Ukraine: Lenvit, 2006. (in Ukrainian).

[3] O. Kotenko, and Yu. Rudnik, "Modelling the Process of primary School Teachers' Training to Use Innovative Technologies of Foreign Languages Teaching", Imidzh suchasnoho pedahoha, vol. 10 (169), c. 34-39, 2016.

[4] O. Kmit, Structure and Content of Professional Competence of English Language Teacher of Primary School, [Online]. Available: http://bo0k.net/index.php?p=achapter\&bid=14834\&chapter=1. Accessed on: July 10, 2017. (in Ukrainian).

[5] O. Kmit, "Content of Informational Competence of English Language Teacher of Primary School", Visnyk Chernihivskoho natsionalnoho pedahohichnoho universytetu im. T. H. Shevchenka, vol. 110, pp. 222-224, 2013. (in Ukrainian).

[6] I. Kostikova, Future Foreign Language Teacher Training by Means of Information and Communication Technologies. Kharkiv, Ukraina: Kolehium, 2008. (in Ukrainian).

[7] O. Pometun, "Theory and Practice of Consecutive Realization of Competence Approach in Foreign Countries Experience", in Competence Approach in Modern Education: World Experience and Ukrainian Prospects: Library of Educational Policy, O. V. Ovcharuk, Eds. Kyiv, Ukraina: K.I.S., 2004, pp. 16-25. (in Ukrainian).

[8] V. Bykov, V. Kremen, "Space and Environment Categories: Features of Model Representation and Educational Implementation", Teoriia i praktyka upravlinnia sotsialnymy systemamy / [Online]. // - 2013. №2. - C. 3-16. -Accessed: http://lib.iitta.gov.ua/id/eprint/1188. (in Ukrainian). Accessed on: July 9, 2017.

[9] K. Bugaychuk, "Electronic Textbook: Concept, Structure, Requirements", Informatsiini tekhnologii $i$ zasoby navchannia, vol, 2(22), 2011. [Online]. Available: http://www.journal.iitta.gov.ua. Accessed on: July 9, 2017. (in Ukrainian).

[10] I. O. Ishutina, "Using Interactive Technologies for the Monitoring of Professional Linguomethodological Competence of Prospective Ukrainian Language Teachers", Profesionalizm pedahoha: teoretychni I metodychni aspecty, vol. 2, pp. 155-163, 2015. [Online]. Available: http://pptma.dn.ua/files/2015/2/19.ishutina.155-163.pdf Accessed on: July 10, 2017. (in Ukrainian).

[11] Common European Recommendations for Language Education: Studying, Teaching, Assessment. S. Yu. Nikolaieva, Eds. Kyiv: Lenvit, 2003.

[12] V. M. Kukharenko, "System Approach to the Blended Learning", Informatsiini tekhnolohii v osviti, vol. 24, pp. 53-67, 2015. DOI:10.14308/ite000568. (in Ukrainian).

[13] M. Simonson, S. Smaldino, M. Albright and S. Zvacek, Teaching and learning at a distance: foundations of distance education, 5th Edition. University of Kansas, US, 2012. (in English).

This work is licensed under Creative Commons Attribution-NonCommercial-ShareAlike 4.0 International License. 